\title{
GEOCHEMISTRY AND SM-ND DATING OF AMPHIBOLITES OF ESEKA GREEN STONES BELT (NYONG COMPLEX SOUTH CAMEROON): HIGHLIGHTING OF DISTENSIVE EPISODES IN A COMPRESSIVE OROGENIC CONTEXT
}

DOI: https://doi.org/10.18509/GBP210445m

UDC: 552.48.08(671.1)

\author{
Tsama Mbani Geneviève ${ }^{1}$ \\ Ekollo Kingue Ngolle Serge ${ }^{1}$ \\ Tchouffa Bertrand Boris ${ }^{1}$ \\ Ndong Bidzang François ${ }^{2}$ \\ ${ }^{1}$ Department of Exploration, XPLORTEC SA, P.O. Box 1921, Yaoundé, Cameroon \\ ${ }^{2}$ Ore Processing Laboratory, Institute of Geological and Mining Research, P.O. Box 4110, \\ Yaoundé, Cameroon
}

\begin{abstract}
The Eséka Greenstone Belt (CRVE) is located in the Nyong Paleoproterozoic unit, Northern edge of the Congo craton, Cameroon. The petrographic, geochemical, and isotopic geochemistry (Sm-Nd) approach of this Nyong complex amphibolites, allowed to highlight three petrographic facies (plagioclastic amphibolites, melanocratic amphibolites and garnet amphibolites), with mineralogical assemblies more or less similar to Hornblende and plagioclase. Fifteen amphibolites samples distributed throughout the CRVE were collected and differentiated into three main facies (garnet, plagioclastic and melanocratic amphibolites). The thin sections were made at the Langfang Rock Detection Technology Services Ltd laboratory in China. The major elements were analysed by X-ray fluorescence (XRF) in South Africa. Isotope geochemical analyses were achieved at the University of Rennes in France. The analyses were carried out following the isotopic dilution method using a multicollector mass spectrometer by thermos-ionization of the Finnigam MAT 262 type to decipher the isotopic composition of samples. Garnet amphibolites are on average richer in silica (47.40 - 52.58\%) compared to plagioclastic and melanocratic amphibolites. The alkali content is low in melanocratic amphibolites, in particular for $\mathrm{K} 2 \mathrm{O}(0.13-0.14 \%)$. These metabasites have several common geochemical features such as: the relatively high contents of Y (22.03 - 39 ppm), Zr (63.78 - $481.99 \mathrm{ppm})$, Th $(0.55-12.37 \mathrm{ppm})$, the low content of Ta ( $0.33-1.20 \mathrm{ppm})$; a high concentration of compatible elements $(5.60 \%$ $<\mathrm{MgO}<13.86 \%, 64.37<\mathrm{Ni}<622.98$ and $230<\mathrm{V}<322 \mathrm{ppm})$ and parallel spectra moderately enriched in light rare earths compared to heavy rare earths $(1.41<\mathrm{LaN} / \mathrm{YbN}$ <22.97). The CRVE amphibolites had 147Sm / 144Nd ratio values varying from 0.0841 to 0.1046 , associated by negative $\varepsilon N d$ values (-28.52 to -19.33$)$. These relatively low values, typical of crustal rocks derived from the continental crust. The CT ages (between $\sim 2092$ and $\sim 2418 \mathrm{Ma}$ ), were interpreted as intermediate ages between the events recorded in the Paleoproterozoic $(\sim 2.05 \mathrm{Ga}-\sim 2.5 \mathrm{Ga})$ and the major Eburnean event $(\sim$ $2.1 \mathrm{Ga})$. These formations show a basaltic protolith with an original composition of subalkaline magmas with tholeiitic affinity. The amphibolites of CRVE derive on the one hand from the tholeiites established in an anorogenic context coming from a weakly enriched mantle source and on the other hand, amphibolites with calcium-alkaline affinity established in an orogenic context. These CRVE amphibolite characteristics, suggested
\end{abstract}


distensive (and/or transtensive) episodes in a compressive orogenic context for their implementation.

Keywords: Amphibolites, CRVE, Sm-Nd dating, Distensive, Geochemistry.

\section{INTRODUCTION}

The continental crust contains approximately 350 volcano-sedimentary belts of about 1.4 million $\mathrm{km} 2$ and only around forty are reasonably well documented. The Congo Craton is a set of Archean and Paleoproterozoic greenstone belts [1], [2], [3], [4]. Although the petrographic and geochemical characteristics are formally well identified, their geodynamic context still remains controversial. Some authors expected displacement processes around the paradigms of plate tectonics [5], [6], [7], [8]. While others relied on the more vertical and diapirically processes [9], [10], [11] and the importance of mantle feathers [12], [13], [14]. In Cameroon, greenstone belts were identified in the Ntem [15], [16] and Nyong [17], [18], [19] complexes. The Lolodorf-Ngomedzap green stone belt (CRVL) dated around $3.06 \mathrm{Ga}$ [16] remains in the relic state within the intrusive granitoids of the Nyong unit set up around $2.9 \mathrm{Ga}$. It was characterized by the metabasites and iron quartzites association. The basic facies of CRVL are clino and orthopyroxene graniferous orthoamphibolites originating from dolerites and gabbros transformations. They showed the association of tholeiitic and calc-alkaline sequences. Based on Sm-Nd model ages, a lower Archean age was selected for the establishment and metamorphism of the CRVL [16] and the amphibolites of Mvengue, between 3.3 and 3.6 Ga (Fig. 1). Cartographically, the limits between the CRVL and CRVE were very hypothetical since they were all located in the area where metabasites and iron quartzites were abundant within the ribbon series (Fig. 1b). This paper describes the geochemistry and geochronology (Sm-Nd) of Eséka Greenstone Belt (CRVE) amphibolites. The purpose being to know whether the CRVE amphibolites (Nyong complex) would be an extension of those of CRVL (Ntem complex) with a common or different context origin.

\section{GEOLOGICAL CONTEXT}

In Southern Cameroon, the Ntem, Nyong and Ayina complexes represent the Congo Craton North-West edges and are composed of granulitic gneiss and a charnockitic intrusive complex set up around $2.9 \mathrm{Ga}$ [4], [16], [20], [21], [22]. The greenstones belts set up between 3.0 and $3.3 \mathrm{Ga}$ in a context of proto-oceanic rift as well as a whole of metamorphic rocks of amphibolitic to granulitic facies, associated with the establishment of granitoids dated to 2.6-2.9 Ga are recognized in the Ntem complex. [23], [24], [25]. The Nyong complex formations mark the end of the Eburnean cycle in Cameroon [26], [27], [28] where the paleoproterozoic chain structuring resulting from the collision between the Congo and São Francisco cratons is set between 2.1 and 2.0 Ga. The CRVE belongs to the Nyong complex [17]. It is surrounded by laminated series [29] formed by garnet mylonites towards the South-East, by the CRVL towards the South [29] and by the Pan-African formations of the Yaounde group towards the North (Fig. 1). The CRVE is lithologically characterized by metabasites (amphibolites, grenatites, eclogites) and ferrifere quartzites association. It is intruded by a vein made up of muscovite pegmatites and ultrabasite. Undifferentiated gneisses and intrusive rocks (alkaline syenites, tonalites) fill the complexity of this geological whole rocks [30]. The CRVE is structurally marked by a D2 deformation phase which takes up the D1 old Liberian EW structures, a 
generalized NE-SW foliation and subvertical seam shears and tangential tectonics with South-East vergence responsible for the overlap of Nyong unit on Ntem unit [31]. These tectonic and metamorphic characteristics confirm a much more vigorous structural evolution than the unity of Ntem during the Eburnian orogeny and of the influence of pan-African tectonics [25].

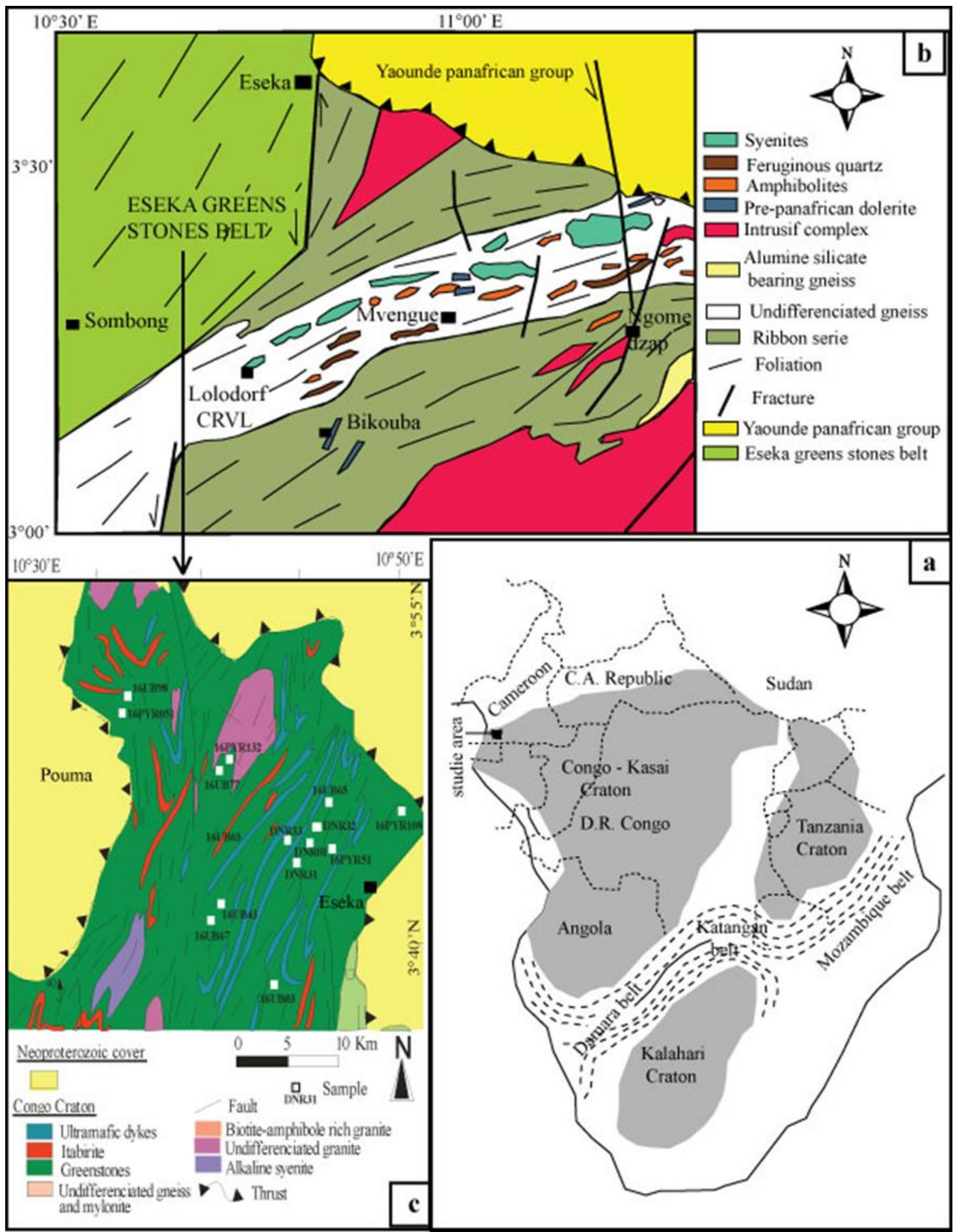

Figure 1: Geological setting of the study: a) Geological diagram showing the position of the

Congo-Kasai, Tanzania and Kalahari cratons in Africa and the layout of the Pan-African belts [51];

b) Geological map of the Eseka - Lolodorf region (modified by [15];

c) Geological map of the Eseka region showing the Eseka greenstone belt. 


\section{ANALYTICAL METHODS}

About fifteen amphibolite samples distributed throughout the CRVE were collected and differentiated into three main facies (garnet, plagioclastic and melanocratic amphibolites). The thin sections were made at the Langfang Rock Detection Technology Services Ltd laboratory in China. Major elements were analysed by X-ray fluorescence (XRF) with the Phillips PW 1840 device and trace elements by mass spectrometry coupled to induction plasma (ICP-MS) on a VG-Plasma Quad STE ICP mass spectrometer at the SANAS laboratory of the ALS group (Australian Laboratory Services) in South Africa. Works carried out by [32] and [33] describe the analytical procedure. The analytical uncertainties were $1 \%$ for major elements, between 5 and $10 \%$ for trace elements, $5 \%$ for rare earths $>10 \mathrm{ppm}$ and $10 \%$ for trace elements $<10 \mathrm{ppm}$. Isotope geochemical analyses were achieved at the University of Rennes in France. The analyses were carried out following the isotopic dilution method [32]. Based on this method, the isotopic composition of samples was done using a multicollector mass spectrometer by thermos-ionization of the Finnigam MAT 262 type. The Nd isotopic ratios were corrected for mass fractionation by normalizing to $146 \mathrm{Nd} / 144 \mathrm{Nd}=0.7219$. Total procedural blanks were b80 pg for Nd. Measurements of the Ames Nd standard gave a mean $143 \mathrm{Nd} / 144 \mathrm{Nd}$ ratio of $0.512125 \pm 8(2 \sigma, \mathrm{n}=5)$. Errors are given in 2 sigma (95\%) confidence level.

\section{RESULTS}

\section{Petrographic characteristics of the amphibolites of Eseka}

The petrographic study revealed three amphibolitic facies: plagioclastic, melanocratic and garnet facies (Fig. 2). These facies were exposed in ball-shape and block-shape on bed and edge of watercourses or as intrusive veins interspersed with other metamorphic rocks (gneiss, mylonites, ultrabasites, quartzites and iron formations). Garnet amphibolites (Fig. $2 \mathrm{a}$ and $2 \mathrm{~b}$ ) had a dark appearance and represent the most dominant facies. The texture was granoblastic to coronitic. The primary assembly was amphibole + garnet + plagioclase + biotite \pm pyroxene. Secondary minerals were sphene, quartz, epidote and opaque minerals. Garnets were very abundant in the rock and sometimes have crowns of quartz and feldspar crystals. The plagioclastic amphibolites (Fig. 2c and 2d) showed a granoblastic to epidoblastic texture. Hornblende, plagioclase and quartz formed the main assemblage of the rock. Pyroxene appeared in the upper amphibolite facies.

While ferro-titanium oxides, quartz, chlorite, biotite, zircon and opaque minerals constituted the accessory minerals. Melanocratic amphibolites (Fig. 2e, 2f) had a dark appearance with fine grains and a massive structure on the ground. The main mineralogical assembly was amphibole + plagioclase. The opaque minerals + epidote + biotite constitute the secondary assembly. The texture was granoblastic unbeds. The epidote was secondary in rock and occurred in the form of clusters. These crystals were generally into interstices and sometimes in inclusions into the amphibole.

\section{Whole-Rock Chemistry and Nature of the Protoliths}

The facies chemical data of analysed samples on total rocks are presented in Table 1. It appeared that, the CRVE amphibolites had $\mathrm{SiO} 2$ contents ranging from 46.63 till 52.58\%. The $\mathrm{K} 2 \mathrm{O}$ contents varied from one facies to another and from one sample to another. They were ranked from 0.13 to $1.81 \%$ suggesting an oxide post-magmatic remobilization. The $\mathrm{CaO}$ obtained values varied between 8.50 and $13.19 \%$ and those of $\mathrm{Al} 2 \mathrm{O} 3$ between 
8.70 and $14.85 \%$ which prove their mobility. $\mathrm{Fe} 2 \mathrm{O} 3$ contents changed between 11.44 and $16.63 \%$; $\mathrm{TiO} 2$ contents are generally low, less than $2 \%$ and $\mathrm{P} 2 \mathrm{O} 5$ contents are also very low, varying between 0.06 and $0.30 \%$.
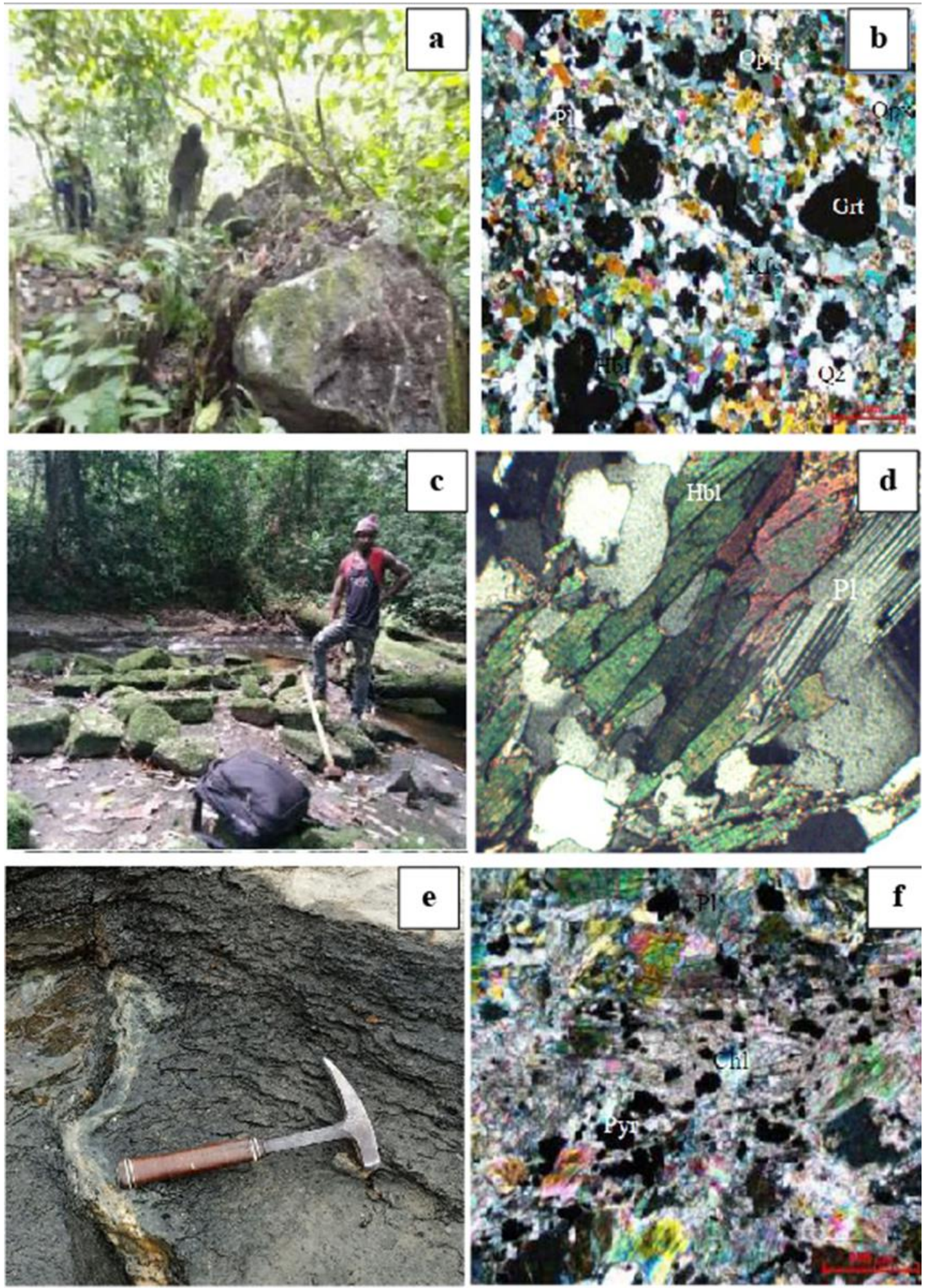

Figure 2: Petrographic characteristics of amphibolites in the Eséka Greenstone Belt 
CRVE amphibolites have relatively high Y (22.03 - 39 ppm), Zr (63.78 - 481.99 ppm), Th $(0.55-12.37 \mathrm{ppm})$ and low Ta $(0.33-1.20 \mathrm{ppm})$ contents. The compatible elements were present in high concentrations $(5.60 \%<\mathrm{MgO}<13.86 \%, 64.37<\mathrm{Ni}<622.98$ and $\mathrm{V}$ between 230 and $322 \mathrm{ppm}$ ), which indicate the presence of primitive liquid among the studied rocks.

In the [34] prototypes triangular diagram, the samples representative points (Fig. 3a) are plotted at the end of the magmatic ridge near the basalts/gabbros. This point arrangement reveals that the studied metamorphic rocks were of magmatic origin. The TAS diagram of Le [35] refines a basaltic protolith on amphibolites (Fig. 3b). Like amphibolites of the Lolodorf-Ngomedzap greenstone belt, CRVE amphibolites have chemical compositions of alkaline basalts [29]. Apart from 16UB67 and 16UB65 samples which had $\mathrm{Y} / \mathrm{Nb} \approx 2$, all the samples show Y/Nb ratios much greater than 2 and Ti/V less than 50 (Fig. 3d). According to [36], such values exclude an alkaline affinity for these rocks whose original composition is similar to that of sub-alkaline magmas (Fig. 3b). The low values of Hf/Th ratios $(0.38$ - 3.84) $<5$, suggest calc-alkaline basalts characteristic of the volcanic arcs. These rocks have a tholeiitic affinity as illustrated by the AFM classification diagram (Fig. 3c) by [37]. Rare earths diagram (Fig. 3e) normalized with respect to chondrites [38] showed that the spectra were parallel and moderately enriched in light rare earths (LREE) compared to heavy rare earths (HREE) $(1.41<\mathrm{LaN} / \mathrm{YbN}<22.97)$. A positive or negative anomaly was observed in $\mathrm{Tm}, \mathrm{Er}, \mathrm{Pr}$ and $\mathrm{Eu}$, reflecting the role operated by plagioclastic feldspar.

Table 1: Major, trace and rare-earth elements distribution in whole fractions of CRVE amphibolites

\begin{tabular}{|c|c|c|c|c|c|c|c|c|c|c|c|c|c|c|}
\hline \multirow[b]{2}{*}{ Sample } & \multicolumn{6}{|c|}{ Garnet bearing amphibolite } & \multicolumn{5}{|c|}{ Plagioclastic bearing amphibolite } & \multicolumn{3}{|c|}{ Melanocratic amphibolite } \\
\hline & $\begin{array}{l}16 \text { UB } \\
77\end{array}$ & 16UB92 & 16UB03 & 16UB65 & DNR01 & DNR31 & DNR32 & DNR33 & 16UB98 & 16UB43 & 16UB67 & $\begin{array}{l}16 \text { PYR0 } \\
51 \\
\end{array}$ & \begin{tabular}{|l}
16 PYR1 \\
32 \\
\end{tabular} & \begin{tabular}{|l|} 
16PYR1 \\
08
\end{tabular} \\
\hline & $\mathrm{w} t \%$ & $\mathrm{wt} \%$ & $\mathrm{wt} \%$ & $\mathrm{wt} \%$ & $\mathrm{wt} \%$ & $\mathrm{wt} \%$ & $\mathrm{wt} \%$ & $\mathrm{wt} \%$ & wt $\%$ & $\mathrm{w} t \%$ & $\mathrm{wt} \%$ & $\mathrm{wt} \%$ & $\mathrm{wt} \%$ & $\mathrm{wt} \%$ \\
\hline $\mathrm{SiO}_{2}$ & 52.58 & 49.07 & 48.44 & 49.58 & 48.20 & 47.40 & 47.26 & 47.00 & 46.63 & 48.78 & 47.72 & 48.52 & 47.96 & 48.73 \\
\hline $\mathrm{TiO}_{2}$ & 1.08 & 1.07 & 0.91 & 0.56 & 0.81 & 1.18 & 1.34 & 1.06 & 1.18 & 1.09 & 0.97 & 0.86 & 0.91 & 0.95 \\
\hline $\mathrm{Al}_{2} \mathrm{O}_{3}$ & 14.48 & 14.85 & 13.22 & 13.73 & 13.08 & 8.92 & 10.33 & 9.50 & 8.70 & 13.74 & 9.06 & 13.23 & 13.53 & 13.98 \\
\hline $\mathrm{Fe}_{2} \mathrm{O}_{3}$ & 12.61 & 13.73 & 13.87 & 11.44 & 12.90 & 16.63 & 16.44 & 14.71 & 16.59 & 13.60 & 15.40 & 13.16 & 14.04 & 14.47 \\
\hline $\mathrm{MnO}$ & 0.19 & 0.19 & 0.20 & 0.18 & 0.23 & 0.24 & 0.23 & 0.21 & 0.25 & 0.19 & 0.22 & 0.21 & 0.21 & 0.22 \\
\hline $\mathrm{MgO}$ & 5.60 & 6.46 & 8.37 & 9.90 & 9.65 & 12.17 & 10.30 & 12.74 & 12.21 & 7.26 & 13.86 & 9.41 & 8.75 & 8.42 \\
\hline $\mathrm{CaO}$ & 8.50 & 9.96 & 9.48 & 9.45 & 13.19 & 9.34 & 9.82 & 10.04 & 9.33 & 9.73 & 9.74 & 12.50 & 11.96 & 11.00 \\
\hline $\mathrm{Na}_{2} \mathrm{O}$ & 3.59 & 3.27 & 2.19 & 3.01 & 1.64 & 1.19 & 2.20 & 1.98 & 1.11 & 3.45 & 1.47 & 1.71 & 2.02 & 2.02 \\
\hline $\mathrm{K}_{2} \mathrm{O}$ & 0.68 & 0.73 & 1.81 & 1.08 & 0.13 & 1.47 & 0.39 & 0.90 & 1.47 & 0.87 & 0.54 & 0.14 & 0.13 & 0.13 \\
\hline $\mathrm{P}_{2} \mathrm{O}_{5}$ & 0.18 & 0.14 & 0.20 & 0.21 & 0.13 & 0.20 & 0.14 & 0.23 & 0.20 & 0.30 & 0.06 & 0.14 & 0.15 & 0.11 \\
\hline LOI & 0.12 & 0.16 & 0.16 & 0.27 & 0.04 & 0.07 & 0.64 & 0.72 & 0.82 & 0.91 & 0.62 & 0.07 & 0.07 & 0.01 \\
\hline Total & 99.58 & 99.61 & 98.82 & 99.41 & 99.98 & 98.79 & 99.08 & 99.07 & 98.47 & 99.89 & 99.67 & 99.93 & 99.71 & 100.04 \\
\hline & $\mathrm{ppm}$ & $\mathrm{ppm}$ & $\mathrm{ppm}$ & $\mathrm{ppm}$ & $\mathrm{ppm}$ & $\mathrm{ppm}$ & $\mathrm{ppm}$ & $\mathrm{ppm}$ & $\mathrm{ppm}$ & $\mathrm{ppm}$ & $\mathrm{ppm}$ & $\mathrm{ppm}$ & $\mathrm{ppm}$ & $\mathrm{ppm}$ \\
\hline $\mathrm{Ag}$ & 12.35 & 18.12 & 17.62 & 15.56 & $<0,01$ & 7.40 & 19.28 & 23.68 & 18.77 & 17.65 & 12.31 & 0,01 & 0,01 & $<0,01$ \\
\hline As & 1.01 & 5.18 & 5.00 & 1.22 & 1.87 & 5.03 & 0.94 & 0.72 & $\begin{array}{l}0.76 \\
\end{array}$ & 0.90 & 3.93 & 0.21 & 0.43 & 4.47 \\
\hline $\mathrm{Ba}$ & 158.81 & 319.22 & 428.64 & 1850.30 & 89.00 & 430.10 & 366.32 & 666.98 & 475.73 & 453.34 & 1338.42 & 88.00 & 90.00 & 67.67 \\
\hline $\mathrm{Be}$ & 2.86 & 3.90 & 3.99 & 6.49 & 7.21 & 4.29 & 3.41 & 4.40 & 3.50 & 5.22 & 4.51 & 4.31 & 7.65 & 5.29 \\
\hline Co & 82.13 & 41.61 & 38.34 & 41.89 & 58.80 & 38.82 & 53.55 & 51.50 & 50.28 & 47.05 & 43.95 & 57.80 & 54.80 & 55.87 \\
\hline $\mathrm{Cr}$ & 692.37 & 116.48 & 369.71 & 410.46 & 602.50 & 370.52 & 310.48 & 583.21 & 563.71 & 346.27 & 303.46 & 499.50 & 331.00 & 237.67 \\
\hline Cs & 1.45 & 2.87 & 3.58 & 2.47 & 3.32 & 3.69 & 1.57 & 1.73 & 2.27 & 2.96 & 1.77 & 3.46 & 5.98 & 3.42 \\
\hline $\mathrm{Cu}$ & 153.98 & 145.61 & 67.55 & 31.08 & 133.75 & 66.03 & 198.43 & 101.45 & \begin{tabular}{|l}
120.37 \\
\end{tabular} & 121.43 & 95.31 & 123.75 & 115.25 & 75.83 \\
\hline
\end{tabular}




\begin{tabular}{|c|c|c|c|c|c|c|c|c|c|c|c|c|c|c|}
\hline $\mathrm{Ga}$ & 30.23 & 43.90 & 43.96 & 124.62 & 6.50 & 44.33 & 42.70 & 83.25 & 42.76 & 83.78 & 70.80 & 7.50 & 6.50 & 10.67 \\
\hline In & 13.08 & 62.93 & 13.84 & 32.26 & 0.79 & 12.87 & 13.34 & 13.61 & 16.21 & 13.80 & 21.14 & 3.64 & 0.93 & 1.28 \\
\hline Mo & 2.91 & 4.90 & 2.84 & 4.18 & 0.48 & 2.54 & 3.03 & 2.94 & 0.97 & 4.85 & 2.99 & 0.56 & 1.21 & 0.51 \\
\hline $\mathrm{Nb}$ & 7.24 & 13.10 & 12.56 & 21.97 & 2.25 & 12.59 & 8.23 & 8.42 & 7.69 & 6.36 & 22.58 & 2.25 & 2.25 & 1.83 \\
\hline $\mathrm{Ni}$ & 622.98 & 64.37 & 100.48 & 135.20 & 210.00 & 101.50 & 175.28 & 247.96 & 211.39 & 145.32 & 129.49 & 197.00 & 176.00 & 116.67 \\
\hline $\mathrm{Pb}$ & 9.86 & 17.44 & 17.53 & 24.74 & 0.50 & 17.61 & 15.58 & 19.03 & 15.67 & 20.88 & 18.84 & 0.50 & 1.50 & 2.67 \\
\hline $\mathrm{Rb}$ & 4.61 & 40.11 & 73.89 & 95.40 & 6.12 & 73.96 & 9.76 & 27.66 & 43.55 & 21.99 & 80.87 & 6.12 & 6.12 & 4.41 \\
\hline $\mathrm{Sc}$ & 39.26 & 39.67 & 43.45 & 47.04 & 23.00 & 44.19 & 41.19 & 43.92 & 44.97 & 42.94 & 43.72 & 25.00 & 23.00 & 34.00 \\
\hline $\mathrm{Sr}$ & 207.51 & 518.01 & 436.86 & 851.68 & 68.65 & 437.74 & 333.40 & 512.65 & 252.25 & 458.25 & 737.47 & 67.65 & 67.65 & 53.43 \\
\hline $\mathrm{Ta}$ & 0.48 & 1.01 & 1.02 & 0.90 & 0.33 & 1.06 & 0.52 & 0.49 & 0.53 & 0.43 & 1.20 & 0.34 & 0.46 & 0.57 \\
\hline Th & 0.82 & 10.92 & 12.37 & 2.96 & 0.75 & 12.35 & 1.47 & 2.93 & 2.92 & 1.94 & 8.77 & 0.70 & 0.72 & 0.55 \\
\hline $\mathrm{U}$ & 0.37 & 4.92 & 4.84 & 0.92 & 0.03 & 4.81 & 0.55 & 0.44 & 0.47 & 0.43 & 3.77 & 0.04 & 0.04 & 0.05 \\
\hline $\mathrm{V}$ & 296.17 & 285.96 & 280.04 & 230.98 & 260.50 & 281.88 & 262.74 & 231.32 & 256.82 & 230.92 & 279.61 & 282.00 & 305.00 & 322.00 \\
\hline W & 0.61 & 1.42 & 1.33 & 0.97 & 0,01 & 1.18 & 0.75 & 0.71 & 0.66 & 1.07 & 0.90 & 0,01 & 0,01 & 0,01 \\
\hline $\mathrm{Yb}$ & 2.04 & 2.34 & 2.57 & 2.55 & 4.01 & 2.35 & 2.35 & 1.92 & 2.58 & 2.21 & 2.32 & 1.24 & 2.33 & 1.43 \\
\hline Y & 23.68 & 39.00 & 38.43 & 29.10 & 23.03 & 38.16 & 29.93 & 26.48 & 29.36 & 26.45 & 37.57 & 22.03 & 22.03 & 29.02 \\
\hline $\mathrm{Zn}$ & 166.04 & 159.78 & 170.78 & 294.59 & 39.00 & 171.17 & 181.37 & 244.86 & 192.37 & 230.53 & 214.72 & 42.50 & 42.50 & 52.67 \\
\hline $\mathrm{Zr}$ & 87.14 & 183.02 & 180.52 & 481.99 & 63.78 & 187.28 & 127.03 & 146.30 & 124.53 & 129.23 & 409.73 & 65.78 & 69.78 & 73.52 \\
\hline $\mathrm{Au}$ & 0,01 & 0,01 & 0,01 & 0,01 & 0,01 & 0,01 & 0,01 & 0,01 & 0,01 & 0,01 & 0,01 & 0,01 & 0,01 & 0,01 \\
\hline $\mathrm{La}$ & 15.03 & 38.30 & 40.37 & 81.60 & 4.53 & 40.42 & 28.40 & 52.02 & 30.47 & 38.40 & 68.36 & 4.43 & 4.59 & 4.08 \\
\hline $\mathrm{Ce}$ & 38.48 & 85.42 & 87.86 & 160.72 & 10.58 & 88.43 & 61.36 & 104.47 & 63.81 & 77.79 & 141.95 & 10.68 & 11.26 & 10.11 \\
\hline $\operatorname{Pr}$ & 10.83 & 16.06 & 15.64 & 15.71 & 0.47 & 15.57 & 12.90 & 9.32 & 12.48 & 12.47 & 16.07 & 0.49 & 0.59 & 0.78 \\
\hline $\mathrm{Nd}$ & 22.43 & 42.24 & 42.34 & 72.12 & 7.75 & 41.48 & 29.26 & 46.39 & 29.36 & 37.19 & 63.69 & 7.63 & 7.55 & 7.17 \\
\hline $\mathrm{Sm}$ & 5.04 & 8.77 & 8.60 & 12.23 & 2.30 & 8.46 & 6.31 & 8.60 & 6.14 & 7.40 & 11.48 & 2.38 & 2.40 & 2.28 \\
\hline Eu & 1.52 & 2.49 & 2.34 & 3.61 & 0.70 & 2.26 & 1.59 & 2.06 & 1.44 & 2.13 & 3.10 & 0.66 & 0.78 & 0.71 \\
\hline $\mathrm{Gd}$ & 5.23 & 8.16 & 7.78 & 9.08 & 2.86 & 7.49 & 6.24 & 7.11 & 5.86 & 6.43 & 9.32 & 2.88 & 3.11 & 3.10 \\
\hline $\mathrm{Tb}$ & 0.76 & 1.14 & 1.07 & 1.14 & 0.48 & 1.06 & 0.92 & 0.93 & 0.86 & 0.88 & 1.25 & 0.49 & 0.52 & 0.55 \\
\hline Dy & 4.55 & 7.11 & 6.76 & 6.05 & 3.88 & 6.52 & 5.49 & 5.22 & 5.14 & 4.89 & 7.29 & 3.83 & 3.92 & 4.10 \\
\hline $\mathrm{Hf}$ & 2.20 & 4.69 & 4.71 & 11.38 & 1.36 & 4.99 & 3.18 & 3.68 & 3.20 & 3.05 & 10.13 & 1.44 & 1.43 & 1.43 \\
\hline Ho & 0.79 & 1.29 & 1.36 & 1.08 & 0.31 & 1.37 & 1.00 & 0.95 & 1.07 & 0.84 & 1.40 & 0.34 & 0.38 & 0.59 \\
\hline Er & 2.22 & 3.79 & 3.73 & 2.76 & 2.50 & 3.66 & 2.87 & 2.55 & 2.82 & 2.42 & 3.70 & 2.41 & 2.46 & 2.56 \\
\hline $\mathrm{Tm}$ & 0.43 & 0.65 & 0.58 & 0.49 & 0.15 & 0.59 & 0.54 & 0.46 & 0.47 & 0.54 & 0.55 & 0.16 & 0.19 & 0.27 \\
\hline $\mathrm{Yb}$ & 3.18 & 5.04 & 4.91 & 3.17 & 2.47 & 4.65 & 3.95 & 3.05 & 3.82 & 4.13 & 3.51 & 2.27 & 2.26 & 2.47 \\
\hline $\mathrm{Lu}$ & 0.32 & 0.58 & 0.60 & 0.37 & 0.39 & 0.58 & 0.43 & 0.36 & 0.45 & 0.35 & 0.54 & 0.37 & 0.36 & 0.40 \\
\hline
\end{tabular}



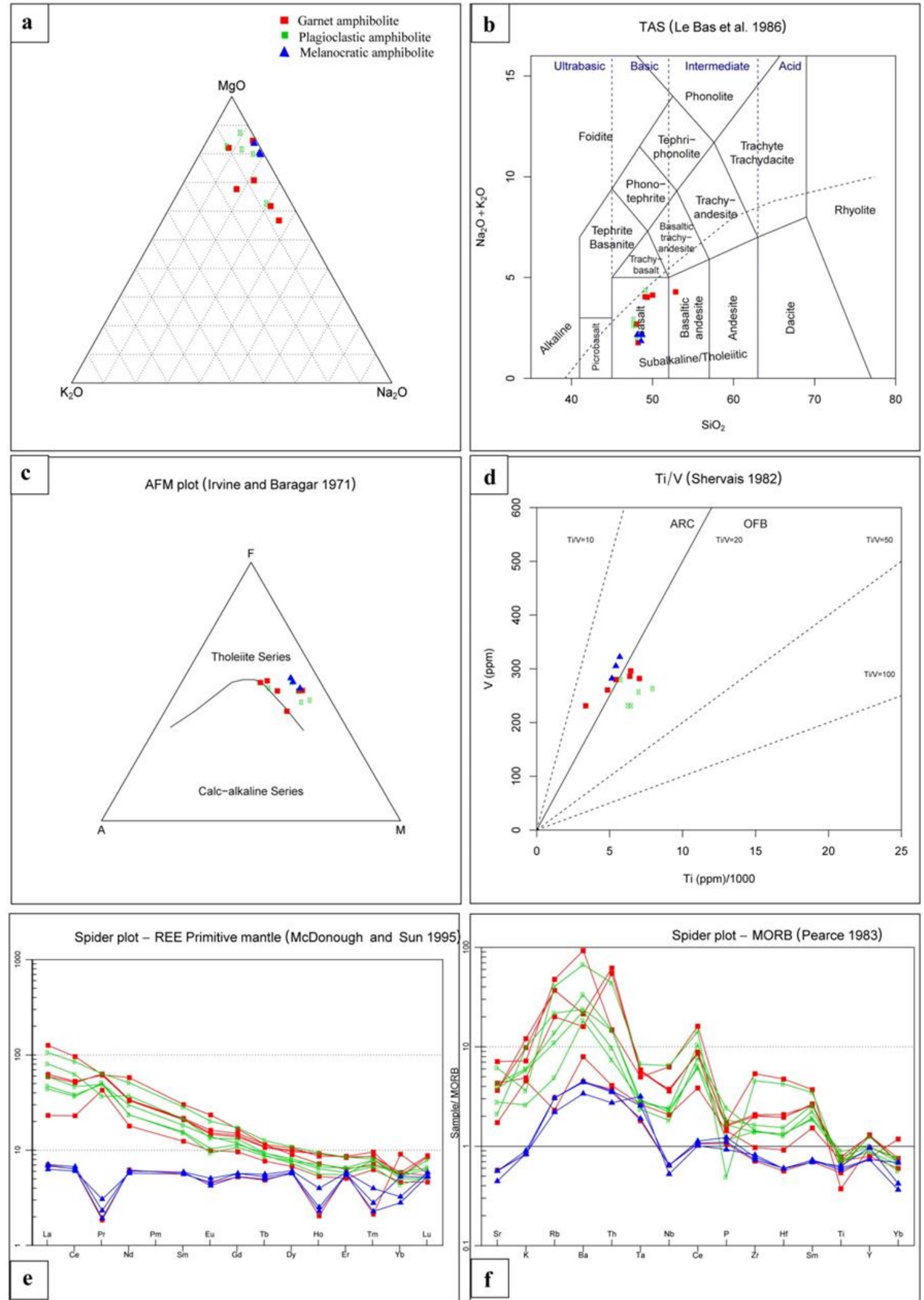

Figure 3: a) Position of the amphibolitic rocks of the CRVE in the triangular diagram (K2O-MgO-Na2O) of [34]; b) TAS diagram of [35] illustrating the basaltic affinity for protolites of CRVE amphibolites; c)

AFM diagram [37] showing the tholeiitic affinity of CRVE amphibolites; d) Ti/V diagram [36], illustrating the tectonic context of CRVE amphibolites ; e) Behaviour of normalized REE with respect to chondrites [38] of the CRVE amphibolites; f) Diagrams normalized to MORBs, showing high variability of mobile $\mathrm{Sr}, \mathrm{K}$ and $\mathrm{Rb}$ in metamorphism. 
Table 2. Isotopic analysis, initial ratios and Nd-model ages of representative samples of CRVE

\begin{tabular}{|c|c|c|c|c|c|c|c|c|}
\hline & Sample & $\begin{array}{l}\mathrm{Sm} \\
(\mathrm{ppm})\end{array}$ & $\begin{array}{l}\mathrm{Nd} \\
(\mathrm{ppm})\end{array}$ & $147 \mathrm{Sm} / 144 \mathrm{~N}$ & $\begin{array}{l}143 \mathrm{Nd} / 144 \mathrm{~N} \\
\text { d }\end{array}$ & $\begin{array}{l}\text { err } \\
2 \sigma m\end{array}$ & ENd & $\begin{array}{l}\text { T (DM) } \\
(\mathrm{Ma})\end{array}$ \\
\hline \multirow{5}{*}{$\begin{array}{l}\text { Garnet } \\
\text { bearing } \\
\text { amphibolite }\end{array}$} & 16UB92 & 4.19 & 20.3 & 0.0991 & 0.511382 & 6 & -24.50 & 2340.9 \\
\hline & 16UB03 & 6.02 & 17.86 & 0.086500 & 0.511183 & 2 & -28.38 & 2346.4 \\
\hline & 16UB65 & 6.11 & 18.85 & 0.094200 & 0.511245 & 3 & -27.17 & 2418.3 \\
\hline & DNR01 & 5.9 & 13.1 & 0.084100 & 0.511176 & 8 & -28.52 & 2311.4 \\
\hline & DNR31 & 4.43 & 22.88 & 0.096100 & 0.511337 & 4 & -25.38 & 2339.3 \\
\hline \multirow{5}{*}{$\begin{array}{l}\text { Plagioclastic } \\
\text { bearing } \\
\text { amphibolite }\end{array}$} & DNR32 & 5.25 & 13.09 & 0.092800 & 0.511241 & 7 & -27.25 & 2395.5 \\
\hline & DNR33 & 4.24 & 22.15 & 0.096200 & 0.511357 & 5 & -24.99 & 2315.6 \\
\hline & 16UB98 & 5.42 & 21.35 & 0.100600 & 0.511407 & 4 & -24.01 & 2338.5 \\
\hline & 16UB43 & 3.87 & 12.38 & 0.1046 & 0.511647 & 7 & -19.33 & 2092.1 \\
\hline & 16UB67 & 2.12 & 13.33 & 0.09885 & 0.511376 & 3 & -24.62 & 2343.8 \\
\hline \multirow{3}{*}{$\begin{array}{l}\text { Melanocratic } \\
\text { amphibolite }\end{array}$} & $\begin{array}{l}\text { 16PYR05 } \\
1\end{array}$ & 2.99 & 13.15 & 0.098200 & 0.511366 & 6 & -24.81 & 2343.7 \\
\hline & $\begin{array}{l}\text { 16PYR13 } \\
2\end{array}$ & 5.38 & 14.55 & 0.10055 & 0.511383 & 3 & -24.48 & 2369.4 \\
\hline & $\begin{array}{l}\text { 16PYR10 } \\
8\end{array}$ & 6.69 & 23.87 & 0.1024 & 0.511458 & 3 & -23.02 & 2307.0 \\
\hline
\end{tabular}

$\mathrm{m}=$ measured isotopic ratios; $\varepsilon \mathrm{Nd}(\mathrm{T})$ values were calculated using present day

$(143 \mathrm{Nd} / 144 \mathrm{Nd}) \mathrm{CHUR}=0.512638$ and $147 \mathrm{Sm} / 144 \mathrm{Nd}) \mathrm{CHUR}=0.1967 ; \mathrm{CHUR}=$ Chondrite Uniform Reservoir; $\lambda=6.54$. 10-12 a-1 [50].

They were between $\sim 2092$ and $\sim 2395$ Ma for the plagioclastic facies. Obtained ages for the garnet facies were in the same range $(2311$ - $2418 \mathrm{Ma})$. Finally, the melanocratic facies indicated very similar ages from 2307 to $2369 \mathrm{Ma}$. These calculated ages for the Sombong migmatitic gneisses on the Nyong river south of Eséka [4] and Bienkop north of Eséka, then for garnet gneiss and garnet and orthopyroxene gneiss at Ngok Tos south of Eséka [28], were interpreted as intermediate ages between events recorded in the Paleoproterozoic $(\sim 2.05 \mathrm{Ga}-\sim 2.5 \mathrm{Ga})$ and the major Eburnean event $(\sim 2.1 \mathrm{Ga})$.

\section{DISCUSSION}

The MORB normalized diagrams (Fig. 3f) show a great variability of mobile Sr, K and $\mathrm{Rb}$ in metamorphism. The very variable levels of $\mathrm{Th}$ and other rare earths in the samples, suggest as demonstrated by [29] in the metabasites of Lolodorf-Ngomedzap and [17] in the Eséka metabasites that these magmas were not cogenitic. In addition, in the Archean metabasites of the Lolodorf-Ngomedzap greenstone belt, the standardized profiles at MORB are presented into three groups [29]: weakly enriched in Th with BABB composition, enriched in Th and enriched in Th and LREE profiles. The CRVE amphibolites present the same profiles with the difference that the weakly enriched in Th profile $(\mathrm{ThN}<10)$ did not show a composition of BABB but of the intermediate domain or continental tholeiite (Fig. 4a).

The $\mathrm{La} / \mathrm{Nb}$ ratio is normally used to distinguish the sources of the lithospheric and asthenospheric mantles [39], [40]. In CRVE amphibolites, the La / $\mathrm{Nb}$ ratio values (1.97 $-6.18)>1.5$ were very high to be linked to a source located in the continental lithospheric mantle [41], [42].

Classic discriminant diagrams such as Zr-Ti-Sr [43]; Fig. 4b) and Zr/Y vs Ti/Y [44]; Fig. 4c) which consider the HFSE immobile in metamorphism, eliminated the intraplate approach and bring the CRVE amphibolites closer to MORB and VAB. This was well illustrated in the ternary diagram Y/15-La/10-Nb/8 [45]; Fig. 4d) where majority of the analysed samples were in the calc-alkaline arc domain with some samples in the field of 
toléiitic arc. In the $\mathrm{Th} / \mathrm{Yb}$ binary vs $\mathrm{Nb} / \mathrm{Yb}$ diagram of [46], the studied rocks were located in the domain of calc-alkaline volcanic rocks of volcanic arc (Fig. 4e). The Tb* 3-Ta * 2-Th diagram (Fig. 4a) by [47] located some samples of CRVE amphibolites in the orogenic domain while others were positioned in the intermediate domain (continental tholeiites).

Based on the age models of neodymium, several protoliths for the studied rocks with a Paleo-Proterozoic age (ages between $2418 \mathrm{Ma}$ and $2307 \mathrm{Ma}$ ) were highlighted. In plagioclastic amphibolites, only one sample shows a younger age of $2092 \mathrm{Ga}$. This age could indicate a differentiation from a differentiated protolith of the Paleoproterozoic mantle, that is, relatively shortly before the major event recorded by these rocks at $\sim 2.05$ $\mathrm{Ga}$ (date of the major Eburnean event well identified at the African continental level, in particular in the West African, Congo, Saharian and Touareg, and the Kalahari cratons) [28], [26], [48]. The Nd isochron (Fig. 4f) gave an age of $2270 \pm 410 \mathrm{Ma}$ (initial isotope ratio $143 \mathrm{Nd} / 144 \mathrm{Nd}=0.50963 \pm 0.00045, \mathrm{MSWD}=5.5)$.

This Paleoproterozoic age is not different from that obtained by evaporation in the Eburnian metabasites of Ngovayang or by U-Pb in the Eséka formations [28], [4], despite an offset of $410 \mathrm{Ma}$ for a very good standard deviation (MSWD = 5.5), thus indicating that there was certainly another younger event of around $410 \mathrm{Ma}$ which affected the $\mathrm{Nd}$ composition of these rocks. The CRVE amphibolites joined those of the lower Archean of Lolodorf-Ngomedzap with various compositions.

These formations derived firstly from tholeiites set up in an anorogenic context (coming from a weakly enriched mantle source) and from amphibolites with calc-alkaline affinity set up in an orogenic context. CRVE amphibolites suggested distensive (and/or transtensive) episodes in a compressive orogenic context for their implementation, as demonstrated by [49] in the Archean metabasites of Amsaga in eastern Mauritania.

\section{CONCLUSION}

Amphibolites of the Eséka sector, with previously studied basic and ultrabasic rocks, form the belt of Nyong paleoproterozoic green rocks called CRVE with relatively similar geochemical and geochronological features. Similar to the lower Archean amphibolites of the Lolodorf-Ngomedzap greenstone belt, those of CRVE have chemical compositions which exclude an alkaline affinity and eliminate the intraplate context by bringing them closer to basalts of mid-oceanic wrinkles (MORB) and basalts of volcanic arches (VAB). A structural study could allow to better explore the tectonic phenomena of this important Cameroonian basement portion in order to better characterize the boundaries between CRVE and CRVL. 


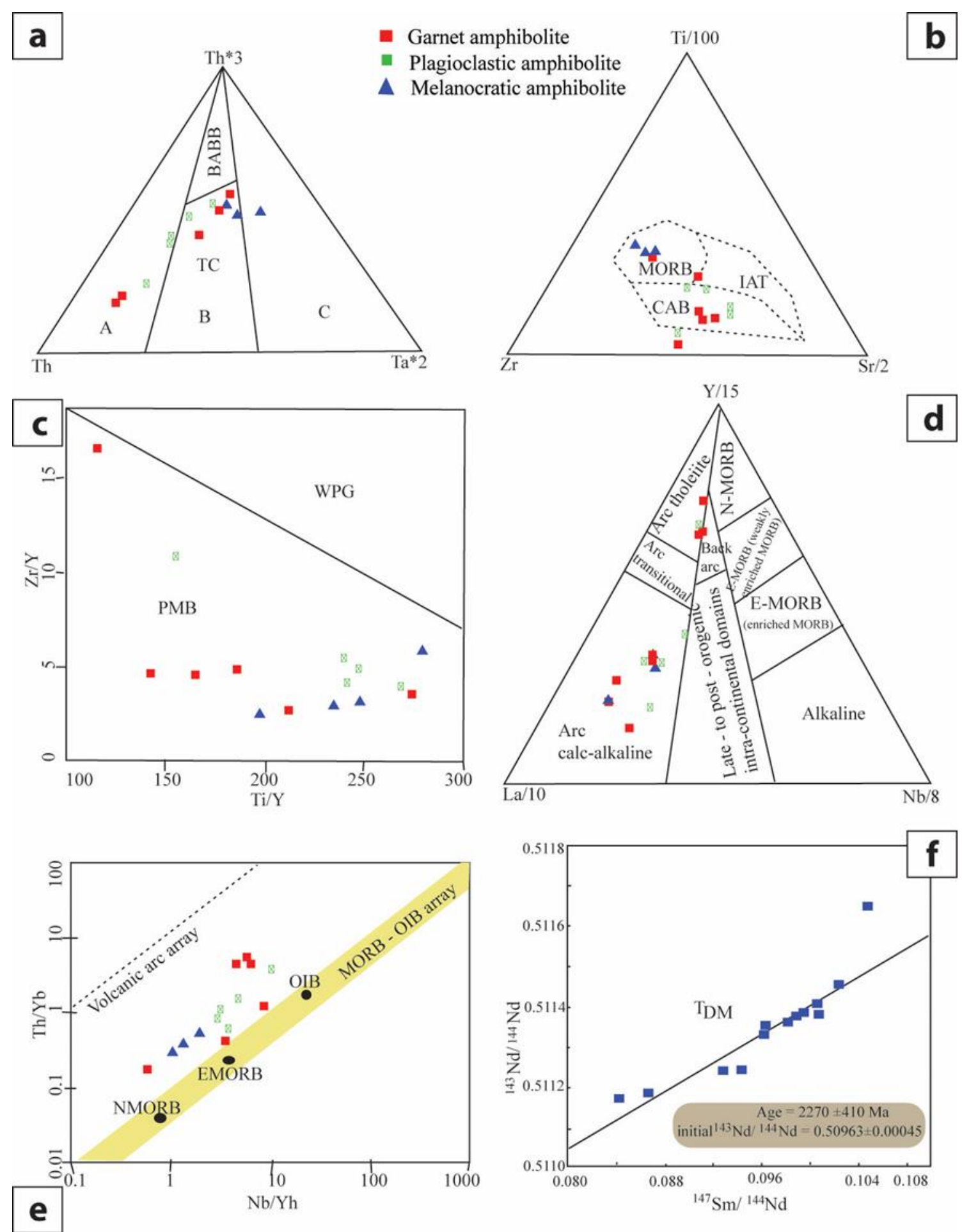

Figure 4: a) Th-Tb*3-Ta*2 diagram of [47]. A: orogenic domain. B: intermediate domain. C: anorogenic domain. BABB: basalts of the back-arc basins. TC: Continental Tholeiites; b) Basalt tectonic discrimination [43]; c) Zr/YvsTi/Y discrimination diagram of [44]. WPG: Intraplate basalts, PMB: plate edge basalts; d) Ternary diagram Y/15-La/10-Nb/8 [45] illustrating the geodynamic context of CRVE amphibolites; e) Binary diagram $\mathrm{Th} / \mathrm{Yb}$ versus $\mathrm{Nb} / \mathrm{Yb}$ of [46] illustrating the geodynamic context of CRVE amphibolites; f) Isochrone of Neodyne 


\section{Acknowledgement}

Our gratitude goes first to the reviewers who improved the quality of the content of this paper. Warm recognitions are also addressed to the SANAS laboratories in South Africa; Langfang Rock Detection Technology Services Ltd in China and the Rennes University in France for the good quality of data provided.

\section{REFERENCES}

[1] Trompette, R. Gondwana evolution; its assembly at around $600 \mathrm{Ma}$. Comptes Rendus de l'Académie des Sciences, Sciences de la Terre et des Planètes, vol. 330, pp. 305-315, 2000.

[2] Moloto A.K.G.R., Trindale, R.I.F., Monié, P., Nédélec, A., Siqueira, R. A late neoproterozoic paleomagnetic pole for the Congo craton tectonic setting, paleomagnetism and geochronology of the Nola dike swarm (Central Africa Republic). Precambrian research, vol. 164, pp. 214-226, 2008.

[3] Alvarez Ph. La transition Précambrien-Cambrien en Afrique centrale. Approche intégrée : paléo-environnements et données paléontologiques. Habilitation à Diriger des Recherches (HDR), Univ. Poitiers (France), Faculté des Sciences Fondamentales \& Appliquées, p. 333, (2000).

[4] Toteu, S. F., Van Schmus, W. R., Penaye, J., Michard, A. New U-Pb and Sm-Nd data from North-Central Cameroon and its bearing on the pre-pan African history of Central Africa. Precambrian Research, vol. 108, pp. 45-73, 2001.

[5] De Wit, M.J. on archean, greenstones, cratons and tectonics ; does the evidence demand a verdict ? presc. Res., vol. 91, pp. 181-226, 1998.

[6] Burke, K. foreword. In : De Wit, M.J. \& Ashwal, L.D. Eds., Greenstone Belt. Oxford monographs on geology and geophysics, no 35, pp. V-VII, 1997.

[7] Windley, B.F. The Evolving Continents, 3rd edn. John Wiley and Sons, Chichester, pp. 526, 1995.

[8] Dewey, J.F. \& Windley, B.F. growth and differentiation of continental crust. Philos. Tans. Roy. Soc. London Ser. A. vol. 301, pp. 189-206, 1981.

[9] Hamilton,P. J., O'nions, R.K. et Evenson, N. M. Sm-Nd dating of archean basin and ultrabasic volcanic rocks. Earth Planet. Sci. Lett., vol. 36, pp. 263-268, 1977.

[10] Goodwin, A.M. principles of Precambrian geology. Academic Press, London, pp. 327, 1996.

[11] MacGregor, A.M. some millestones in the Precambrian of the Southern Rhodesia. Geol. Soc. Afri. Proc., vol. 54, pp. 27-71, 1951.

[12] Abbott, D. H. \& Isley, A. E. The intensity, occurrence, and duration of superplume events and eras over geological time. Journal of Geodynamics, vol. 34, no 2, pp. 265-307, 2002.

[13] Tomlinson, K.Y. \& Condie, K.C. Archean mantle plumes: evidence from greenstones belt geochemistry. In: R.E. Emst and K.L. Buchan (Eds.), Mantle Plumes. Their identification Through time. Geol. Soc. Amer. Spec.Paper, vol. 352, pp. 341-357, 2001.

[14] Davies, G.F. Plates and plumes : dynamos of the Earth's mantle. Science, vol. 257, pp. 493494, 1992.

[15] Vicat J.-P. Bilan des connaissances acquises sur les séries de Dja (Cameroun), Nola (Centrafrique) et Sembé-Ouesso (Congo), in : Vicat J.-P., Bilong P. (Eds.), Géosciences au Cameroun, Collect. GEOCAM, Press. Univ. Yaoundé I, 1/1998, pp. 369-383, 1998.

[16] Tchameni, R. Géochimie et géochronologie des formations de l'Archéen et du Protérozoïque du sud-Cameroun (groupe du Ntem, Craton du Congo). Thèse Université d'Orléans, pp. 35, 1997. 
[17] Ndema Mbongue J. L., Ngnotue T., Ngo Nlend C. D., Nzenti J. P., Cheo Suh E. Origin and Evolution of the Formation of the Cameroon Nyong Series in the Western Border of the Congo Craton. Journal of Geosciences and Geomatics, vol. 2, no. 2, pp. 62-75, 2014.

[18] Nkoumbou, C., Barbey, P., Yonta-Ngouné, C., Paquette, J.L., Villiéras, D.F. Precollisional geodynamic context of the southern margin of the Pan-African fold belt in Cameroon. Journal of African Earth Sciences, vol. 99, pp. 245-260, 2014.

[19] Ebah, A. S. A., Ndjigui, P. D., Beyann, A. A., Teutsong, T., Bilong, P. Geochemistry of pyroxénites, amphibolites and their weathered products in the Nyong unit, SW Cameroon (NW border of Congo craton) : implication for Au-PGE exploration. Journal of Geochemical exploration, vol. 114, pp. 1-19, 2012.

[20] Cahen, I., Snelling, N. G., Delhal, J., Vail, J. R. The geochronology and evolution of Africa. Clarendon Press, Oxford, PP. 512, 1984.

[21] Lasserre et Soba. Ages cambriens des granites de Nyibi et de Kongolo (Centre-Est Cameroun). Comptes Rendus de l'Académie des Sciences, vol. 283, pp. 1696-1698, 1976.

[22] Delhal, J. et Ledent, D. Musée Royal Afrique Centrale. Tervuren Rapport Annuel, pp. 7176, 1975.

[23] Nédélec, A., Nsifa, E.N. Le complexe du Ntem (Sud Cameroun) : une série tonalitotrondhjemitique archéenne typique. In : Matheis and schandelmeier (Eds.), Current research in African Earth Sciences, Balkema, Rotterdam, pp. 2-4, 1987.

[24] Tchameni, R., Nsifa, N. E. Revue des données géochronologiques sur la partie Nord-Ouest du Craton du Congo (groupe du Ntem) Sud-Cameroun. In Géosciences au Cameroun, Vicat T. P. et Bilong P., Editors, Collection GEOCAM 1, Presses Université de Yaoundé I, pp. 339- 350, 1998.

[25] Nédélec, A., Nsifa, N. E., and Matin, H. Major and trace element geochemistry of the Archaean Ntem plutonic complex (South Cameroon): petrogenesis and crustal evolution. Precambrian Research, vol. 47, pp. 35-50, 1990.

[26] Penaye, J., Toteu, S.F., Tchameni, R., Van Schmus, W.R., Tchakounté, J., Ganwa, A., Miyem, D., Nsifa, E.N. The 2.1 Ga West Central African Belt in Cameroun: extension and evolution. Journal of African Earth Sciences, vol. 39, pp. 159-164, 2004.

[27] Tanko Njiosseu, E. L., Nzenti, J. P., Njanko, T., Kapajika, B., Nédélec, A. New U-Pb Zircon ages from Tonga (Cameroon): Coexisting Eburnean Transamazonien $(2.1 \mathrm{Ga})$ and Pan-African (0,6 Ga) imprints. Comptes Rendus de l'Académie des Sciences, vol. 337, pp. 551-562, 2005.

[28] Lerouge, C., Cocherie, A., Toteu, S. F., Penaye, J., Milesi, J. P., Tchameni, R., Nsifa, N. E., Fanning, C. M., Deloule, E.,. SHRIMP U/Pb zircon age evidence for paleoproterozoic sedimentation and $2.05 \mathrm{Ga}$ syntectonic plutonism in the Nyong Group, South-western Cameroon: consequences for the eburnean-transamazonian belt of NE Brasil and central Africa. Journal of African Earth Sciences, vol. 44, pp. 413-427, 2006

[29] Vicat, J.P., Pouclet, A., Nsifa E. Les dolérites du groupe du Ntem (Sud Cameroun) et des régions voisines (Centrafrique, Gabon, Congo, Bas Zaïre) : Caractéristiques géochimiques et place dans l'évolution du craton du Congo au Protérozoïque. In : J. P. Vicat, and P. Bilong, Eds., Géologie et environnements au Cameroun. Collection GEOCAM: 1999, pp. 305-324, 1996.

[30] Nsifa, N. E., Tchameni, R., Nédélec, A., Siqueira, R., Pouclet, A., Bascou, J. Structure and petrology of Pan-African nepheline syenites from the South West Cameroon; Implications for their emplacement mode, petrogenesis and geodynamic significance. Journal of African Earth Sciences, vol. 87, pp. 44-58, 2013.

[31] Maurizot, P., Abessolo, A, Feybesse, J.L., Johan V. and Lecomte P. Etude et prospection minière du Sud-Ouest Cameroun. Synthèse des travaux de 1978 à 1985. Rapport BRGM, Orléans 85, CMR 066, pp. 274, 1986. 
[32] Ndong B. F., Ntomba S. M., Ntomb Y. D., Messi O. E. J., Magnekou T. R. C. Sm-Nd and $\mathrm{Rb}$-Sr Datings, Petrogenesis and Thermometry of the Ngovayang Area (South-West Cameroon): Isotopic Data Insight of Recycling Crust and Convergence Orogen. Science Research, vol. 7, no. 2, pp. 17-32, 2019.

[33] Ongboye, P. R. B., Sababa, E., Ndong, B. F., Ndjigui, P. D. Geochemical characterization of surface sediments from Tongo Gandima (Eastern Cameroon): implications for gold exploration. Arabian Journal of Geosciences, vol. 85, pp. 9-21, 2019.

[34] De la Roche. H. Sur l'existence de plusieurs faciès géochimiques dans les schistes paléozoïques des Pyrénées luchonnaises. GeologischeRundschau, vol. 55, pp. 274-301, 1965.

[35] Le Bas, M.J., Le Maitre, R.W., Streckeisen, A., Zanettin, B. A chemical classification of volcanic rocks based on the total alkani-silica diagram, IUGS subcommission on the systematic of igneous rocks. Journal of petrology, Vol. 27, Issue 3, pp. 745-750, 1986.

[36] Shervais, J.W. Ti-V plots and the petrogenesis of modern and ophiolitic lavas. Earth Planet. Sci. Lett., vol 59, pp. 101-118, 1982.

[37] Irvine, T. \& Baragar, N. A guide to the chemical classification of the common volcanic rocks. Canadian Journal of Earth Sciences, 8, 523-548, 1971.

[38] Mc Donough, W.F. \& Sun, S.S. The composition of the Earth. Chemical Geology, vol. 67, no. 5, pp. 1050-1056, 1995.

[39] Fitton J.G., James, D., Kempton, P.D., Ormerod, D.S., Leeman, W.P. The role of lithospheric mantle in the generation of late Cenozoic basic magmas in the western United States, in: X. Cox, Y. Menzi (Eds.), Oceanic and continental lithosphere: similarities and differences, Journal of Petrology (special issue), 331-349, 1988.

[40] Thompson, R. N., Morrisson, M. A., Hendry, G. L. and Parry, S. J. An assessment of the relative role of crust and mantle in magma genesis. An element approach. Philosophical Transactions of the Royal Society London, vol. 310, pp. 549-590, 1988.

[41] Hawkesworth, C., Turner, S., Gallagher, K., Hunter, A., Bradshaw, T., Rogers, N. Calcalkaline magmatism, lithospheric thinning and extension in the Basin and Range. Journal of Geophysical Research, vol. 100, pp. 10271-10286, 1995.

[42] Rogers, N.W., Hawkesworth, C., Ormerod, C.J. Late Cenozoic basaltic magmatism in the Western Great Basin California and Nevada. Journal Geophysical Research, vol. 100, pp. 1028710301, 1995.

[43] Pearce, J. A., Cann, J. R. Tectonic setting of basic volcanic rocks determined using trace element analyses. Earth and Planetary Science Letters, vol. 19, pp. 290-300, 1973.

[44] Pearce, J.A. \& Gale, G.H. identification of ore-deposition environment from trace element geochemistry of associated igneous host rocks. Geol. Soc. Spec. Publ., vol. 7, pp. 14-24, 1977.

[45] Cabanis, B, Lecolle, M. 1989. The La/10-Y/15-Nb/8 diagram; a tool for distinguishing volcanic series and discovering crustal mixing and/or contamination. Comptes Rendus de l'Académie des Sciences, Paris, 309, 2023-2029, 1989.

[46] Pearce, J.A. Geochemical fingerprinting of oceanic basalts with applications to ophiolite classification and the search for Archean oceanic crust. Lithos, vol.100, no. (1-4), pp. 14-48, 2008.

[47] Cabanis, B. \& Thieblemont, D. la discrimination des tholéiites continentales et des basaltes arrière-arc. Proposition d'un nouveau diagramme, le triangle Th-3xTb-2xTa. Bulletin Société Géologique de France, vol. 8, tome IV, no.6, pp. 927-935, 1988.

[48] Carvalho, P.C.S., Neiva, A. M. R., Silva, M. M. V. G., Corfu, F. A unique sequential melting mechanism for the generation of anatectic granitic rocks from the Penafiel area, northern Portugal. Lithos, vol. 155, pp. 110-124, 2012. 
[49] Hamoud A., El Hadi H., Chakiri S., Tahiri A. Caractérisation pétrographique et géochimique des métabasites archéennes d'Amsaga Est (dorsale de régueïbat, Mauritanie). European Journal of Scientific Research, vol. 135, no. 3, pp. 228-242, 2015.

[50] Steiger, R.H and Jager E. Subcommission on geochronology: Convention on the use of decay constants in geo- and cosmochronology. Earth and Planetary Science Letters, Vol. 36, pp. 359362, 1977.

[51] Batumike, J., Griffin, W.L., O'reilly, S.Y., Belousova, E., Pawlitschek, M. Crustal evolution in the central Congo-Kasai Craton, Luebo, D.R.Congo: insights from zircon U-Pb ages, Hfisotope and trace-element data. Precambrian research, Vol. 170, 1, pp. 107-115, 2009. 